


Bridging Research \& Practice

\title{
A Case of a Partnership Academy Small Learning Community Model on Student Outcomes
}

\author{
Sheila Folan \\ Sacramento, CA \\ smfolan@yahoo.com
}

Cary J. Trexler

College of Education

University of California, Davis

cjrtrexler@ucdavis.edu 


\title{
JOURNAL OF YOUTH DEVELOPMENT \\ bridging research and practice

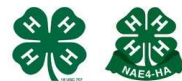

Volume 3, Number 1, Summer 2008

Article 080301FA005

\section{A Case of a Partnership Academy Small Learning Community Model on Student Outcomes}

\author{
Sheila Folan \\ Sacramento, CA \\ Cary J. Trexler \\ University of California, Davis
}

\begin{abstract}
Many students are experiencing disconnect from their large, seemingly impersonal high schools. This case study research explored a post-high school class cohort's perceptions of an academy environment. The study examined the nature of its connection to academic, behavioral and post-secondary effects by utilizing a treatment group of academy students and a comparison group of non-academy students. The study found that students within academies experienced a greater sense of high school community than non-academy students. Differences were also found in post-secondary endeavors including greater participation by academy students in college, the workforce and career/technical areas.
\end{abstract}

\section{Introduction}

United States educators have assumed the role of not only educating their charges, but also providing social support networks for them as well. Amidst political and societal pressures, U.S. secondary school administrators, teachers and support staff have strived to come to terms with their responsibility to provide an educational environment that connects students to school while addressing the call for heightened achievement levels.

Disconnected young adults are those who are neither in school nor the workplace. Over 700,000 young people fit that description, which equates to a 19\% rise from 1999 through 2002 (Whitlock, 2003). Prospects for young adults who have not connected to school or their community are jeopardized as they transition into adulthood. A disturbing trend surfaced in 2002 when it was discovered that $15 \%$ of U.S. 18 to 24 year olds were disconnected (Whitlock, 2003). 
A sense of community contributes to a successfully functioning society and can potentially play a role in ameliorating school dropout rates. Researchers (Bryk \& Driscoll, 1988; Hill, Foster \& Gendler, 1990) found schools act as their own segments of society and function as communities that contribute to school outcomes. As the diverse needs of students increase, the importance of community and the connectedness that stems from it also grows. Jones (2006) found that the most positive youth-adult relationship experiences were those with supportive adults willing to share power with youth, those instituting youth-led endeavors where young people were allowed to demonstrate high levels of involvement and responsibility, and those involving participants who had previously worked as a community partner.

School connectedness can be defined as the degree to which a student experiences a sense of caring and closeness to teachers and the overall school environment (Bonny, 2000). This connectedness has effects on student academic achievement as it builds relationships between the learner and the members of the institution. Most important amongst these relationships are those forged between students and teachers. Croninger and Lee (2001) found that although other members of the school community are significant, the teacher-student relationship provides special support. This is particularly true of students who come from socially disadvantaged backgrounds (Croninger \& Lee, 2001).

High School dropouts often report not having a strong interest or sense of belonging in school. When asked why they left, one third cited not liking school as well as poor relationships with teachers. Both factors demonstrate features of connectedness. Weak connectedness was also associated with increased health risk that contributes to students' inability to focus on learning (Bonny, 2000). Blum (2005) found seven characteristics that reflected students' connectedness to school:

- Having a sense of belonging and being part of a school

- Liking school

- Perceiving that teachers are supportive and caring

- Having good friends within school

- Being engaged in their own and future academic progress

- Believing that discipline is fair and effective

- Participating in extracurricular activities

Through analysis of the National Longitudinal Study of Adolescent Health (Harris, 2003) Blum and Rhinehart (1997) associated school level characteristics that influenced school connectedness. In a related study, researchers found that school connectedness was a powerful protective factor. Students who felt connected were less likely to use alcohol and illegal drugs, to engage in violent or deviant behavior, to become pregnant or to experience emotional distress (Blum, 2002). A recent study upheld data demonstrating that youth engagement in service to others and their community plays a role in reducing high risk behaviors (Rodine, et al, 2006).

National research of 254 public secondary schools showed that school factors such as communal school organization and student bonding were predictive of school behaviors. Greater communal organization and student bonding led to less delinquency and victimization (Payne, Gottfredson \& Gottfredson, 2003).

In school communities where students feel safe from harm and humiliation they experience greater attachment and commitment. Parsons (2004) suggested that when students feel safe, 
they are more likely to take risks because they have the security to succeed and feel supported as they put out their best efforts.

Educational administrators are increasingly aware of harmful effects of large schools on low SES students (Howley, 2000). As a result, innovators have sought new school structures to combat the well-documented influences of large schools. Welburn (1999) has argued that an academy mode/seems to be the most feasible way to downsize schools and have become one of the fastest growing school reforms. Lynch (2000a) agreed in his examination of the principles of school improvement when he cited academies in his list of top high school reforms.

Rubin (2002) found that career academies increased the probability that students would attend post-secondary education, improved academic achievement levels, decreased the need for remediation in English at the university, and increased the probability of graduating.

The academy model levels the playing field for all students. Conchas and Clark (2002) illustrated that particularly for low-income minority students, the academy promoted optimism. Increased investments in career-related experiences through academy participation during high school were also found to improve post-secondary labor market prospects (Kemple, Snipes \& Clayton, 2004).

\section{Theoretical Base/Conceptual Framework}

The study's theoretical framework comes from the seminal work of sociologists and community theorists. Ferdinand Tonnies (1887) defined community as not only one of kinship and place, but also, as a community of the mind. Community also occurs amongst individuals brought together by common interests, goals and values and this shared conception of being, creates belongingness and purpose (Craig, Harris \& Weiner, 2002). Society differs, as it is a group of individuals motivated through self-promotion and completion of rational tasks and tangible goals of the social organization (Tonnies, 1887). A community model within a school can be viewed as an amorphous presence that is flexible to the needs of its constituents.

Talcott Parsons (1951) enacted measurements of social relationships by describing their types. He utilized five variable pairs placed on a continuum to assess social relationships. These five dimensions included: affective - affective neutrality; collective orientation - self-orientation; particularism - universalism; ascription - achievement; and diffuseness - specificity (Parsons, 1951). Sergiovanni (1994), utilizing Parson's continuum approach, added two more sets of variables. These included substantive - instrumental and altruism - egocentrism. Four dimensions were selected from Parsons (1951) and Sergiovanni's (1994) work as a part of this study. Each dimension was included as a construct for this study's survey instrument because each was determined to be of import to school community concepts.

Community is essential to a school. As Sergiovanni (2000) put it: "as community wanes in a school, feelings of belonging, of being a part of something important, of having a common purpose, are weakened, and parents, teachers, and students experience a lack of connectedness, disorientation, and isolation" (p. 15). "Community is the tie that binds students and teachers together in special ways. Community can help teachers and students be transformed from a collection of 'I's' to a collective 'we', thus providing them with a sense of identity, belonging and place" (Sergiovanni, p. xiii). 
Although Sergiovanni (1994) asserted that relationships between all school stakeholders are integral to develop a comprehensive profile of a school community, this study undertakes to review student perceptions of relationships between themselves and school staff. It is the manifestation of community within an academy that the authors seek to assess.

\section{Purpose}

The purpose of the case study was to describe the differences for students as they participated in one school's career academy programs. The study sought to describe the effects on student achievement of participation in a small learning community environment. By examining academy students and non-academy participants, a description of the impact of the intervention could be developed. The study was also designed to observe the impact of community on students within academy settings. A survey was used to measure and compare student perceptions of their learning community in relationship to two community dimensions articulated by Parsons (1951) and two other dimensions delineated by Sergiovanni (1994).

\section{Context of the Study}

To determine the influence of the small learning community model on student outcomes, a case study approach was utilized. The study focused on one racially and culturally diverse high school that houses two academies and shall be known for the purpose of this study as North High School (NHS). The two academies were named Academy A (agriculture) and B (business). Each academy closely adhered to the model of a common set of teachers delivering a core academic curriculum with a career and technical education focus in the two aforementioned fields. In addition each program followed similar student recruitment and screening processes to form their small learning community. The academies also had the third commonality of partnerships with employers.

NHS is a large high school currently comprised of 2,355 students. The researchers used archival data to follow students from their ninth grade forward. Academy participation begins in the $10^{\text {th }}$ grade year. The examination yielded differences in holding power amongst groups (Table 1).

Table 1

Holding Power of NHS Class of 2004

\begin{tabular}{|l|c|c|c|c|}
\hline & $\mathbf{9}^{\text {th }}$ & $\mathbf{1 0}^{\text {th }}$ & $\mathbf{1 1}^{\text {th }}$ & $\mathbf{1 2}^{\text {th }}$ \\
\hline Total Students & 655 & 553 & 407 & 310 \\
\hline Non Academy students & 655 & 429 & 290 & 212 \\
\hline Academy A & N/A & 64 & 59 & 44 \\
\hline Academy B & N/A & 60 & 58 & 54 \\
\hline
\end{tabular}

\section{Methodology}

\section{Design of Study}

The researchers used the positivist approach to this descriptive case study. This approach was determined appropriate to explore this situation because the intervention had no single set of outcomes (Yin, 2003). Further, Yin has argued the case study technique is often used to understand complex social phenomena. In this case, the complex social phenomena were student participation in a partnership academy, small learning community and the influences this had on school and non-school outcomes. Yin (1994) has stressed that is incumbent on 
researchers to make case study data conducive to statistical analysis by coding events into numerical form. In this study, two numerically based data sources were used: (1) district archival data for three years and (2) a mail survey.

\section{Population}

This study's population was originally 553 tenth grade students registered at NHS in 2001-2002. At the time of the study, three years later, the contactable student population numbered 486. These students were aged 18 years or more. One hundred twenty were academy students and 366 were non-academy students.

The response rate from the 486 surveys successfully mailed was $46.5 \%$ or 226 individuals. One hundred forty-six were non-academy students and 80 were from the two academies. Fifty of these were Academy A and 30 were Academy B. The 226 survey respondents consisted of 109 males and 117 females. The mean age of respondents was 18.20 years (SD = .45) with an age range of 18 to 20 .

\section{Archival Data}

Quantitative data consisted of assessment of individual student outcomes. To ascertain these outcomes, archival transcript data were analyzed for the class of 2004 for the following years: (a) 2001-2002, (b) 2002-2003, and (c) 2003-2004.

\section{Survey}

A survey was developed based on previous research studies on the relationship of community to learning (DiBartolomeo, 1998) and graduate follow-up models (Kemple, et al., 2004). The instrument consisted of three parts:

(1) demographic information,

(2) post-high school endeavors, and

(3) student perceptions of their learning community as it compared to two dimensions of community articulated by Parsons (1951) and two community dimensions as delineated by Sergiovanni (1994).

The face validity and usability of the instrument were ascertained via a field test with twentythree students who had graduated.

A Cronbach's alpha was performed to assess the survey's internal consistency. This study's questionnaire had four theoretical constructs. These constructs came from the aforementioned work of Parsons and Sergiovanni and were found to be very robust:

- .8635 for Affective to Neutral Affective;

- .8320 for Ascription to Achievement;

- .8771 for Substantive to Instrumental; and

- .7583 for Altruism to Egocentrism.

In addition to the numerical data gathered via the survey, there was one open-ended question. The purpose of this qualitative question was to provide an opportunity for participants to provide additional comments.

\section{Data Analysis}

Archival data and survey data were analyzed and frequency counts, percentages, Chi Squares, t-tests, means and standard deviations were used to describe data. Findings from statistical 
tests were used as a decision rule for declaring differences. As this study was a census, statistical tests assisted in decision making and examining in detail, not for inferential purposes.

For the first two research questions, decision criteria were used to determine findings to report. Although small differences existed in many of the archival data categories, a "big picture" approach was determined appropriate to report findings of most import. A range of percentage differences from $1.2 \%$ through $20.6 \%$ was addressed in the findings. A threshold of differences greater than $3 \%$ was set as an analytical tool for the majority of findings. One below the threshold finding of $1.2 \%$ disconnected students was also included as it was deemed of interest to note to the premise of the study.

\section{Limitations of the Study}

There are two important limitations to this study. First as with most case studies, the present study's findings cannot be generalized to the population at large. Borrowing from the qualitative research paradigm, however, the authors argue particulars described in this case are transferable to other school-based settings that are considering or using small learning communities.

A second limitation is the fact that a causal relationship between participation in the academy and student outcomes cannot be discerned and applied. Although no cause and effect explanation was sought as a result of this study, the authors were aware of potential confounding variables including students being engaged in other school activities that can be likened to the academy model.

\section{Results and Findings}

\section{Research Question One: Were differences noted for holding power and transiency rate for students involved in the academy programs?}

Reviewing holding power, or the proportion of students retained 9-12 in a school, allowed examination of transiency and stability for academy and non-academy students. The academy population experienced a lower transiency rate and increased holding power (Table 2).

Table 2

Transiency and Stability of Study Population

\begin{tabular}{|l|c|c|c|c|c|c|c|}
\hline & 10th & 11th & $\begin{array}{c}\mathbf{1 1}^{\text {th }} \text { Grade } \\
\text { Transiency }\end{array}$ & $\begin{array}{c}\mathbf{1 1}^{\text {th }} \text { Grade } \\
\text { Stability }\end{array}$ & $\mathbf{1 2}^{\text {th }}$ & $\begin{array}{c}\mathbf{1 2}^{\text {th }} \mathbf{G r a d e} \\
\text { Transiency }\end{array}$ & $\begin{array}{c}1^{\text {th }} \text { Grade } \\
\text { Stability }\end{array}$ \\
\hline Total Students & 553 & 407 & $26.4 \%$ & $73.6 \%$ & 310 & $23.8 \%$ & $76.2 \%$ \\
\hline $\begin{array}{l}\text { Non academy } \\
\text { students }\end{array}$ & 429 & 290 & $32.5 \%$ & $67.5 \%$ & 212 & $29.9 \%$ & $73.1 \%$ \\
\hline Academy A & 64 & 59 & $7.9 \%$ & $92.1 \%$ & 44 & $25.4 \%$ & $74.6 \%$ \\
\hline Academy B & 60 & 58 & $3.4 \%$ & $96.6 \%$ & 54 & $6.9 \%$ & $93.1 \%$ \\
\hline
\end{tabular}

Due to the varying transiency rate of the two academies, further explorations were conducted. It was determined that Academy A was more representative of the total school population. Academy B differed more from the general school population in their ethnic makeup (Table 3). The most notable difference occurred within the Asian subgroup of the study population where Academy A had $10.4 \%$ fewer students of Asian descent and Academy B had $9.5 \%$ more students of Asian descent. 
Table 3

Ethnicity of Study Population

\begin{tabular}{|l|l|l|l|l|l|l|l|l|}
\hline Population & $\begin{array}{l}\text { American } \\
\text { Indian }\end{array}$ & Asian & $\begin{array}{l}\text { Pacific } \\
\text { Islander }\end{array}$ & Filipino & Hispanic & $\begin{array}{l}\text { African } \\
\text { American }\end{array}$ & White & Other \\
\hline Non-academy & $.5 \%$ & $33.8 \%$ & $3.1 \%$ & $5.1 \%$ & $17.7 \%$ & $23 \%$ & $15.7 \%$ & $1.1 \%$ \\
\hline Academy A & $0 \%$ & $23.4 \%$ & $4.7 \%$ & $4.9 \%$ & $17.6 \%$ & $23.4 \%$ & $22.9 \%$ & $3.1 \%$ \\
\hline Academy B & $0 \%$ & $43.3 \%$ & $5 \%$ & $1.7 \%$ & $16.7 \%$ & $21.6 \%$ & $11.7 \%$ & $0 \%$ \\
\hline
\end{tabular}

Research Question Two: Were there differences in post-secondary endeavors for students involved in the academy programs? The impact of academies on students' posthigh school endeavors was examined. Through an examination of previous studies (Kemple, et al., 2004; Linnehan, 1996) the areas of post-high school examination were determined.

An examination of status at graduation time was conducted (Table 4). Both the academy programs showed more students graduating at NHS than did the non-academy population. Academy A was again more similar to the non-academy population than Academy B in status at graduation.

Table 4

Status of Students at Graduation Time

\begin{tabular}{|l|l|l|l|l|l|l|l|l|l|}
\hline Population & $\begin{array}{l}\text { NHS } \\
\text { Grad }\end{array}$ & $\begin{array}{l}\text { Other } \\
\text { Comp } \\
\text { HS } \\
\text { Grad }\end{array}$ & $\begin{array}{l}\text { Alt } \\
\text { HS } \\
\text { Grad }\end{array}$ & Moved & $\begin{array}{l}\text { Ongoing } \\
\text { Educat. }\end{array}$ & $\begin{array}{l}\text { Private } \\
\text { School }\end{array}$ & $\begin{array}{l}\text { Failure } \\
\text { to } \\
\text { graduate } \\
\text { HS }\end{array}$ & $\begin{array}{l}\text { Failure to } \\
\text { graduate } \\
\text { after } \\
\text { transfer } \\
\text { to Alt HS }\end{array}$ & Expelled \\
\hline $\begin{array}{l}\text { Non- } \\
\text { academy }\end{array}$ & $49.3 \%$ & $1.9 \%$ & $9.8 \%$ & $9.6 \%$ & $11.7 \%$ & $.7 \%$ & $11.9 \%$ & $4.2 \%$ & $.7 \%$ \\
\hline Academy A & $68.8 \%$ & $1.6 \%$ & $9.4 \%$ & $4.6 \%$ & $9.4 \%$ & $3.1 \%$ & $3.1 \%$ & $0 \%$ & $0 \%$ \\
\hline Academy B & $90 \%$ & $3.3 \%$ & $1.7 \%$ & $3.3 \%$ & $0 \%$ & $0 \%$ & $1.7 \%$ & $0 \%$ & $0 \%$ \\
\hline
\end{tabular}

Note. Grad $=$ Graduates. Comp $=$ Comprehensive. Alt $=$ Alternative. Educat. $=$ Education.

Descriptive statistics were used for this study to provide a heightened awareness of all cohort members. In addition, descriptive statistics were also used to present findings of the survey. To provide a clearer picture of the students in this study, the ethnicity of survey respondents is described in Table 5.

Table 5

Ethnicity of All Respondents

\begin{tabular}{|l|c|r|}
\hline \multicolumn{1}{|c|}{ Ethnicity } & \# Respondents & Percent of Total \\
\hline American Indian & 1 & .44 \\
Asian & 94 & 41.59 \\
Pacific Islander & 7 & 3.10 \\
\hline Filipino & 12 & 5.31 \\
\hline Hispanic & 35 & 15.49 \\
\hline African American & 35 & 15.49 \\
\hline White & 37 & 16.37 \\
\hline Other & 5 & 2.21 \\
\hline
\end{tabular}


The academy population demonstrated a higher enrollment in four-year universities at 35\% compared to $26.7 \%$ for non-academy students (Figure 1 ). Further, academy participants partook of more part and full-time work experience opportunities. In addition, academy students had slightly fewer individuals not working at $5 \%$ compared to non-academy students at $6.2 \%$.

Figure 1

Students' post-secondary endeavors

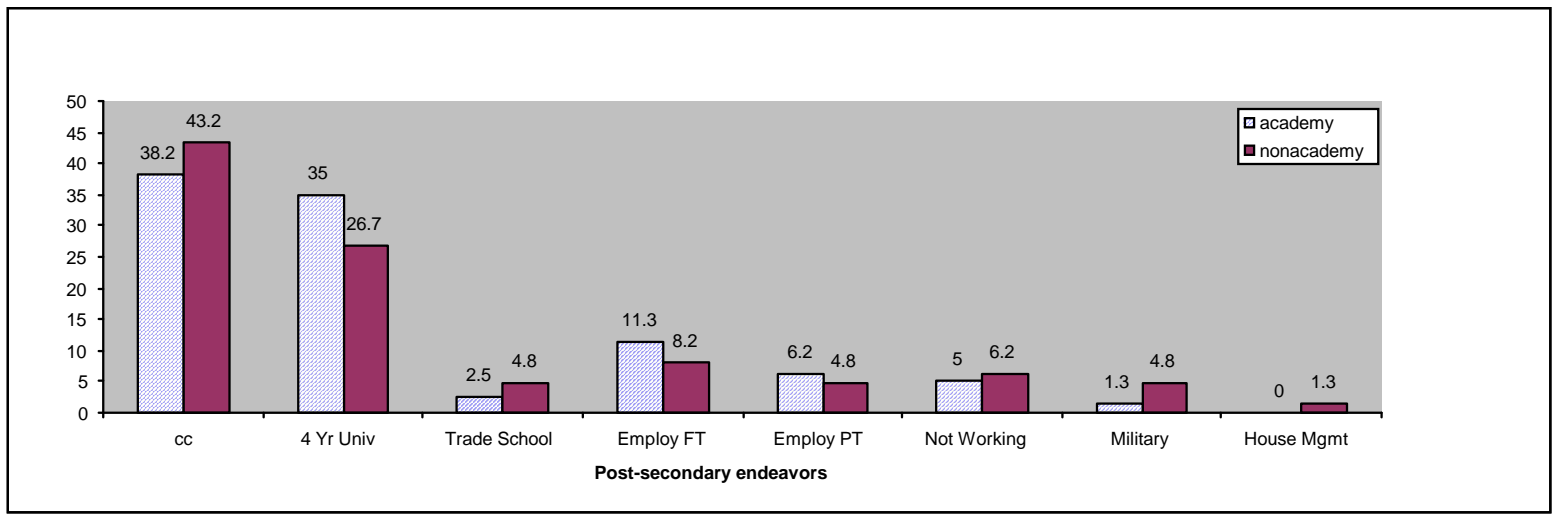

Collegiate Findings. Academy participants had fewer undeclared college majors (29.5\%), than non-academy students (34.9\%) (Figure 2). In the two academy specialization areas of agriculture and business, the academy population demonstrated more students with these as declared majors. Agriculture, as an academy student's major, was $8.2 \%$ and agriculture as a non-academy student's major was $0 \%$. Business, as an academy student's college major, was $16.4 \%$, while non-academy student majored at $11 \%$. Academy students were not involved in trade preparation, but $4.6 \%$ of non-academy students were so engaged. A larger percentage of non-academy students reported majoring in both the life and physical sciences than academy students, while more academy students majored in English or Liberal Arts than non-academy students.

Figure 2

Students' college majors

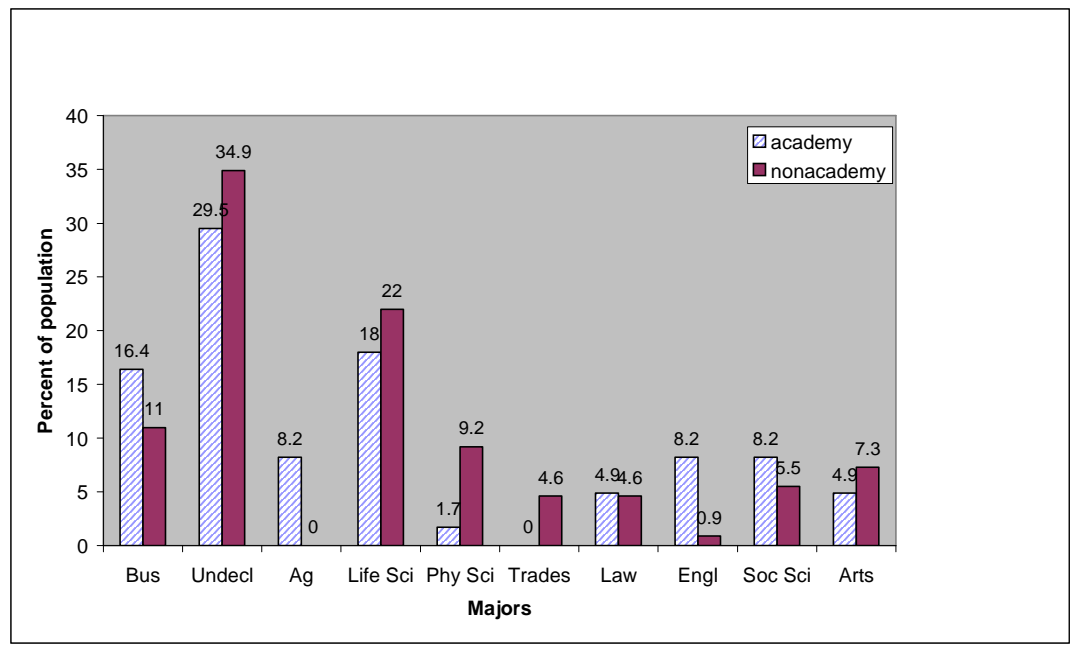


As shown in Figure 3, of those students currently attending college, a greater number of academy respondents (52.4\%) reported that they were carrying full time unit loads of 13 or more units than non-academy respondents (39.4\%).

Figure 3

Number of college semester units



For units completed, the non-academy participants reported having completed 13 or more college units at a higher number than the academy population. This stood at $27.5 \%$ of the nonacademy as compared to $24.6 \%$ of the academy population (Figure 4 ).

Figure 4

Number of units completed

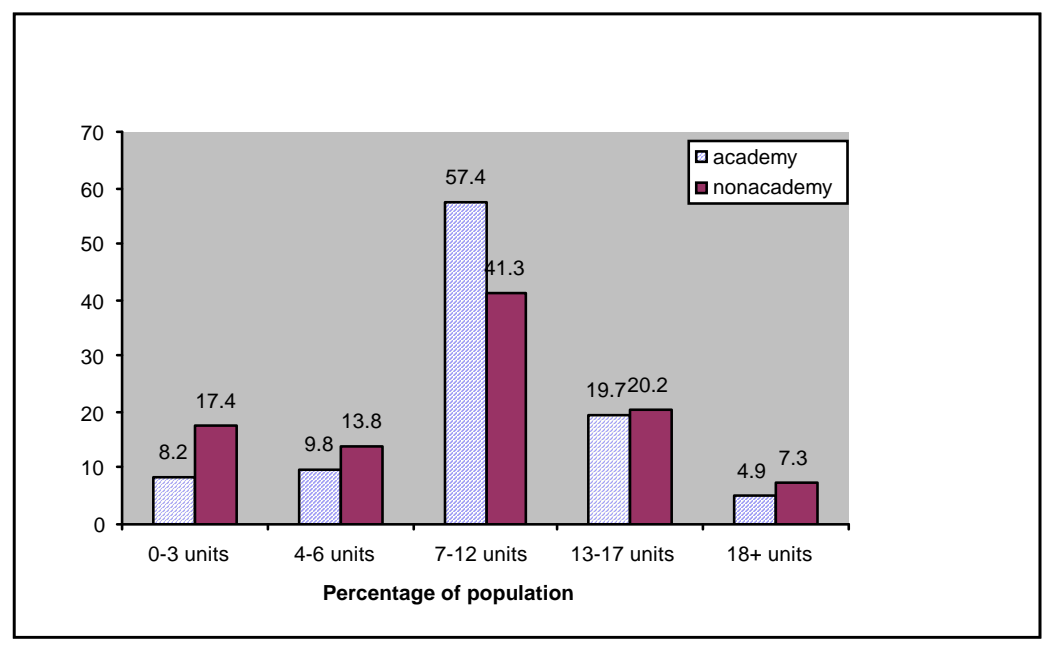

Employment Findings. Utilizing the same self reported survey results, data was garnered on students' employment status and the groups differed in several ways. Non-academy participants reported $4.8 \%$ military service, compared to $1.3 \%$ of academy participants (Figure 1 ). When a subset of those who were working was examined, $25 \%$ of the non-academy population 
reported military service as opposed to $6.7 \%$ of the academy population (Figure 5). In addition, fewer academy participants (26.7\%) were employed in service professions, than non-academy students $(35.7 \%)$.

Agriculture and business academy graduates had higher incidences of employment in these fields than non-academy students. Agriculture employment by academy students stood at $20 \%$ while agriculture by non-academy students was $17.9 \%$. Business employment for academy students stood at $40 \%$ and $14.2 \%$ for non-academy students. Career and technical education areas of employment were all higher for the academy students than the non-academy students. For example, the percentage of students involved in the trades for the academies was $6.7 \%$ compared to $3.6 \%$ for non-academy students (Figure 5 ).

Figure 5

Students' employment fields

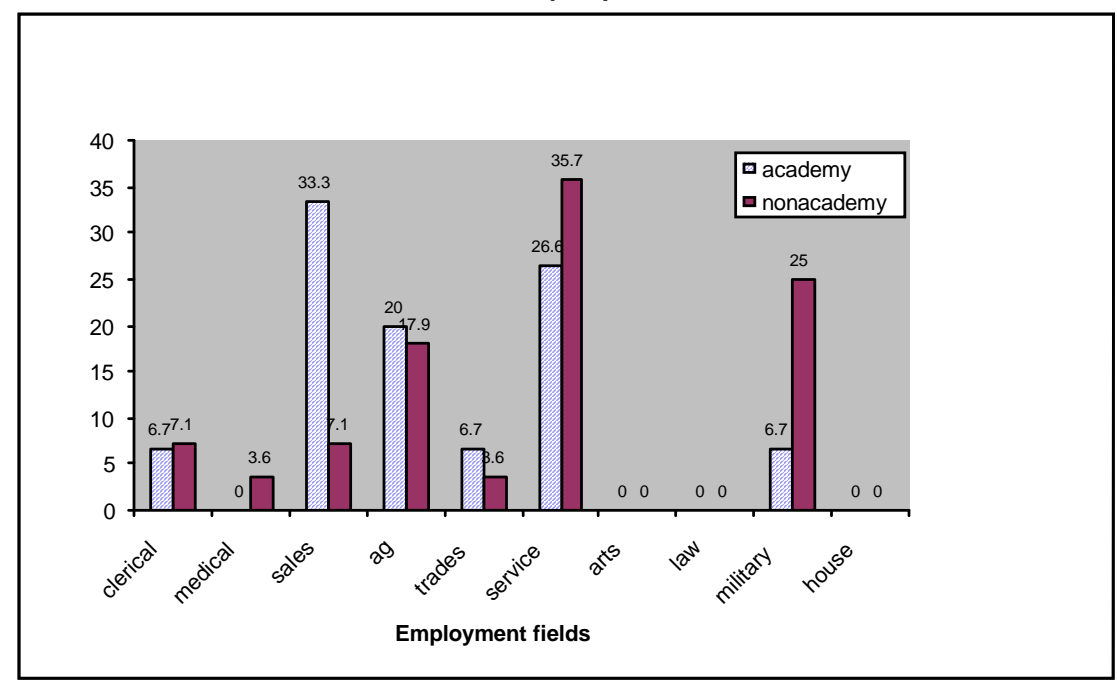

In the realm of weekly hours engaged in work, academy respondents had greater full-time employment of $31-40$ hours at $82.4 \%$ as compared to non-academy respondents at $61.8 \%$ (Figure 6).

Figure 6

Weekly hours of employment




The academy population also had a greater range of salaries as well as a greater dollar amount earned (Figure 7). For academy students, $13.4 \%$ received more than $\$ 2,000$. per month as compared to $0 \%$ of non-academy students.

Figure 7

Students' monthly salary



Research Question Three: Were there differing perceptions of school community for students involved in the academy programs? To determine students' perceptions of school community, mean scores for the four community perception constructs were tabulated. Academy participants had highest mean score (4.34) in the Ascription vs. Achievement construct. Similarly, non-academy participants showed the highest mean response in the Ascription vs. Achievement construct area at 3.68. The lowest mean scores for both groups with scores of 4.13 and 3.53 occurred in the Affective vs. Neutral Affective construct. Means score comparison of the two groups also revealed differences in standard deviations. The academy population demonstrated greater consistency throughout their responses as illustrated in lower standard deviations. The number of respondents remained consistent for all four constructs at 80 for academy students and 146 for non-academy students.

To determine if differences existed between the two groups, independent t-tests were conducted. Differences were found in all four constructs. Academy students had higher mean scores in each community perception construct. 
Table 6

Comparison of Community Perception Means between Academy and Non-academy Participants

\begin{tabular}{|l|c|c|}
\hline Constructs & $\begin{array}{c}\text { Academy } \\
\text { Mean } \\
\text { (SD) }\end{array}$ & $\begin{array}{c}\text { Non-academy } \\
\text { Mean } \\
\text { (SD) }\end{array}$ \\
\hline Affective vs. Neutral Affective & $4.13^{*}$ & 3.53 \\
& $(.67)$ & $(.76)$ \\
\hline Ascription vs. Achievement & $4.34^{*}$ & 3.68 \\
& $(.64)$ & $(.79)$ \\
\hline Substantive vs. Instrumental & $4.29 *$ & 3.65 \\
& $(.60)$ & $(.76)$ \\
\hline Altruism vs. Egocentrism & $4.17^{*}$ & 3.54 \\
& $(.63)$ & $(.76)$ \\
\hline
\end{tabular}

Note. $1=$ not true, $2=$ rarely true, $3=$ sometimes true, $4=$ usually true, $5=$ very true.

$*$ Independent samples $t$-tests found significant differences at the .05 level.

\section{Analysis}

Quantitative methodology was used in this study because it provided a means to examine three indicators of participation in an academy: (a) holding rates of students, (b) post-high school endeavors, and (c) relationships of students' perceptions of community dimensions. The case study format was utilized because it provided a basis for the initial theory of the phenomenon of academies. Although the case study approach can be criticized for its lack of representativeness and scientific rigor, it remains as a viable method for an in-depth investigation using different methods to collect various kinds of information and make observations (Hamel, 1993).

Results from this case study were used to inform educators on the nature of school community in relationship to the academy and student outcomes. This study approach provided a means to delve into one school's experience with the academy intervention method.

Academy students demonstrated greater holding power as evidenced by lower transiency rates and greater stability rates. NHS academies appear to foster community that subsequently connects students to school. The institution of academies within schools requires a strong commitment from all school stakeholder groups but the effort could propel the involved students as well as benefiting society.

In examining further the difference between the two studied academies it was noted that Academy A had fewer Asian students than the non-academy population. Academy B had more Asian students than the non-academy population as well as the greatest number of Pacific Islanders. This has implications for this study's outcomes because according to the U.S. Economics and Statistics Administration Bureau of the Census for the population 25 years and over, Asians and Pacific Islanders have the highest graduation rate from high school (87.4\%) than any other group. In addition, Asians and Pacific Islanders also hold more Bachelor's Degrees (47.2\%) than any other group (U.S. Census Bureau, 2003). Further, the annual median income of Asian and Pacific Islander households is the highest of any group at $\$ 57,313$. (U.S. Census Bureau, 2002).

Academy students illustrated greater post-high school self-direction than their non-academy peers. They have more full and part time employment and higher earnings ratios than their 
non-academy peers. In addition, more academy students were engaged in higher education and fewer were being disconnected from both work and college. NHS academy participation appeared to help reverse the trend noted by Whitlock (2003) of greater numbers of 18-24 year olds being neither employed nor in college. Students' increased sense of community along with their post-secondary engagement suggest that students are able to form connections between high school and their future aspirations furthering their awareness of their potential.

The perception of school community was significantly greater for academy students than nonacademy students. The greatest differences among means in the two groups occurred in the Ascription vs. Achievement construct. These results demonstrate that academy students felt a higher sense of unconditional positive regard around them from staff and peers. Providing opportunities for community within the school setting may be one of the few opportunities for students to experience positive normative influences of a group with norms that are often shared by the majority of society.

\section{Implications for Practice}

A major implication of this study is that fostering community among young people is of paramount import, particularly for students from low SES, large high schools. Connectivity must be in place. Mechanisms to connect teachers, administrators and support staff to students provide a positive environment that can translate into positive post-secondary outcomes for these individuals. Implementing similar school designs to small learning communities is one step towards establishing connections for students. Encouraging students, through social support by their peers and school personnel, translates into one form of support for student learning and post-secondary outcomes. When this can be formalized through establishment of a small learning community, efforts are targeted towards creating supports for student successes.

Extending this study longitudinally to examine how and if the results are sustained into the future could be a fruitful area of future research. Ascertaining what skills are acquired through participation within these learning communities would also provide insights into the effectiveness of this reform mechanism. Other specific explorations could include examining the extent to which connectivity provided by these learning communities promote persistence towards future endeavors. By addressing these circumstances amongst others, school community efforts that connect students can be validated. This school initiative could provide the glue to connect students to school while propelling them towards success.

Small learning communities can potentially counteract some of the societal obstacles that preclude students from seeing the relationship between high school and their future lives. This case study contributes to the growing body of evidence, which shows positive impacts of the academy model of small learning communities on post-secondary outcomes. The study explores community from both the sociological and educational standpoints and endeavors to unite the community aspects of academies with post high school success indicators. 


\section{References}

Blum, R. (2002). The untapped power of schools to improve the health of teens. Minneapolis: Center for Adolescent Health and Development.

Blum, R. (2005). School connectedness: Improving the lives of students. Johns Hopkins Bloomberg School of Public Health, Baltimore, Maryland, 2005.

Blum, R., \& Rhinehart, P. (1997). Reducing the risk: Connections that make a difference in the lives of youth. Minneapolis: Division of Adolescent Health: 12.

Bonny, A. (2000). School disconnectedness: Identifying adolescent risk. Pediatrics, 106(5), 4.

Bryk, A., \& Driscoll, M. (1988). The school as community: Theoretical foundations, contextual influences and consequences for teachers and students. Madison, WI: National Center for Effective Secondary Schools: 19.

Conchas, G., \& Clark, P. (2002). Career academies and urban minority schooling: Forging optimism despite limited opportunity. Journal of Education for Students Placed at Risk, Л3), 287-311.

Craig, W., Harris, T., \& Weiner, D. (2002). Community participation and geographic information systems. New York: Taylor and Francis.

Croninger, R., \& Lee, V. (2001). Social capital and dropping out of high schools: Benefits to at-risk students of teachers' support and guidance. Teachers College Record, 103, 548-581.

DiBartolomeo, J. (1998). Small learning communities and their relationship to school performance outcomes (Doctoral Dissertation, Widener University, 1998).

Hamel, J. (1993). Case study methods. Newbury Park: Sage.

Harris, K.M., Florey, F., Tabor, J., Bearman, P.S., Jones, J., \& Udry, J.R. (2003). The National Longitudinal Study of Adolescent Health: Research Design [WWW document]. URL: http://www.cpc.unc.edu/projects/addhealth/design.

Hill, P., Foster, G., \& Gendler, T. (1990). High schools with character. Santa Monica, RAND: 110.

Jones, K.R. (2006). Relationships Matter: A mixed-methods evaluation of youth and adults working together as partners. Journal of Youth Development, 1(2), 1-11.

Kemple, J., Snipes, J., \& Clayton, J. (2004). Career academies impacts on labor market outcomes and educational attainment. New York, MDRC, 45.

Linnehan, F. (1996). Measuring the effectiveness of a career academy program from an employer's perspective. Educational Evaluation and Policy Analysis, 18(1), 73-89.

Lynch, R.L. (2000a). High school career and technical education for the first decade of the $21^{\text {st }}$ century. Journal of Vocational Education Research 25, 18. 
Lynch, R.L. (2000b). New directions for high school career and technical education in the $21^{\text {st }}$ century. (ERIC No. ED-99-CO-0013).

Parsons, A. (2004). Discovering students' knowledge through observation and community building. Childhood Education, 80(4), 2.

Parsons, T. (1951). The social system. New York: Free Press.

Payne, A., Gottfredson, D., \& Gottfredson, G. (2003). Schools as communities: The relationships among communal school organization, student bonding and school disorder. Criminology, 41(3), 2.

Rodine, S., Oman, R., Vessely, S., Aspy, C., Tolma, E., Marshall, L., \& Fluhr, J. (2006) Potential protective effect of the community involvement asset on adolescent risk behaviors. Journal of Youth Development, 1(1).

Rubin, V. (2002). Career academy programs in California: Outcomes and implementation. Berkeley, California Policy Research Center: 41.

Sergiovanni, T. (1994). Building community in schools. San Francisco, CA: Jossey-Bass.

Sergiovanni, T.J. (2000). The lifeworld of leadership. San Francisco, CA: Jossey-Bass.

Tonnies, F. (1957). Gemeinschaft und Gesellschaft (Community and Society). New York: American Book Company. (Original work published 1887)

U.S. Census Bureau. (2002). Money income in the United States: 2001. Annual demographic supplement to the current population survey. Washington DC: U.S. Government Printing Office.

U.S. Census Bureau. (2003). Poverty, income see slight changes; child poverty rate unchanged. Population survey's annual social and economic supplement. Washington DC: U.S. Government Printing Office.

Welburn, B. (1999). Career academies. Alexandria, National Association of State Boards of Education, 3.

Whitlock, J. (2003). School and community connectedness. Department of Human Development in the College of Human Ecology. Ithaca, Cornell: 110.

Yin, R.K. (1994). Case study research: Design and methods. Newbury Park: Sage.

Yin, R.K. (2003). Case study research: Design and methods. Thousand Oaks, CA: Sage.

(C) Copyright of Journal of Youth Development $\sim$ Bridging Research and Practice. Content may not be copied or emailed to multiple sites or posted to a listserv without copyright holder's express written permission. However, users may print, download or email articles for individual use. 